Journal of Jazz Studies no. 10, no. 2, pp. 203-209 (Winter 2014-2015)

\title{
(Un) Cool Cats: Challenging the Traditional View of the French Response to Jazz
}

\author{
Merve Fejzula
}

Paris Blues: African American Music and French Popular Culture, 1920-1960. By Andy Fry. Chicago and London: University of Chicago Press, 2014. 304 pp. \$30.00.

When jazz was the existentialist accessory of the postwar fifties, it seemed, according to James Baldwin, the very first question on a Frenchman's lips upon meeting an African American was always, "Jouez-vous la trompette?" So much was this the habit (and he was not alone in identifying it) that Baldwin once joked if he were to write a memoir of those years it would be titled, "Non, nous ne jouons pas la trompette." 1

Such essentialization was certainly not an invention of the postwar decade and the anecdote is an example of the difficulty, as Andy Fry has convincingly demonstrated in Paris Blues: African American Music and French Popular Culture, 1920-1960, with the notion that the French were sophisticated appreciators of jazz and African American performance. Using a variety of source material which he scrutinizes in often creative ways, Fry demonstrates that so many assumptions about black performers in France and in Europe are deeply problematic: that they received an early and welcome reception there, that jazz was bound up intimately with the history of the Resistance, and that African Americans did not experience racism in France.

Of course the more complex story of African Americans in France is one not only of racial essentialization, but includes the usual culprits that scholars of the period have identified: exoticism, paternalism, primitivism, fetishism. ${ }^{2}$

\footnotetext{
${ }^{1}$ Quoted in James Campbell, Exiled in Paris: Richard Wright, James Baldwin, Samuel Beckett and Others on the Left Bank (New York: Scribner, 1995), 103.

${ }^{2}$ This includes the work of Petrine Archer-Straw, Negrophilia: Avant-Garde Paris and Black Culture in the 1920s (London: Thames and Hudson, 2000); Brett A. Berliner, Ambivalent Desire: The Exotic Black Other in Jazz-Age France (Amherst: University of Massachusetts Press, 2002); and Elizabeth Ezra, The Colonial Unconscious: Race and Culture in Interwar France (Ithaca, NY: Cornell University Press, 2000); Sieglinde Lemke, Primitivist Modernism: Black Culture and the Origins of Transatlantic Modernism (New York: Oxford University Press, 1998); T. Denean Sharpley-Whiting, Black Venus: Sexualized Savages, Primal Fears, and Primitivist Narratives in French (Durham, NC: Duke University Press, 1999); Marianna Torgovnick,
} 
These historians have noted the complex nature of the French appreciation of black art generally; how the very freedom that was allotted to black artists and attributed to black art could also delimit what these artists were allowed to produce. In other words, to lift an example from Fry's first chapter: while giving black artists and performers the space to perform in venues like the Thêâtre des Champs-Élysées, France would expect nothing more than Blackbirds of 1926 (and 1928, and 1929).

The premise of Paris Blues is that jazz historians have not always caught up to historiographical trend, and he faults some scholars for the tendency to see France and Paris through "rose-tinted spectacles." ${ }^{3}$ Thus, Fry frames his own project as one of unraveling the romantic myths surrounding black music and performance in France, loosely organized around what he calls "case studies." Each of the book's five chapters takes on a different subject: chapter one deals with early African American musical theatre in Paris, chapter two with interwar French jazz criticism through the lens of big bands such as Jack Hylton's, chapter three with the legacy of Josephine Baker via her starring role in a 1933 production of Offenbach's La Créole, chapter four with jazz during the Occupation, re-examining Django Reinhardt, and chapter five on the public memory of jazz by way of Sidney Bechet's career in France.

Although not strictly related in subject matter, these case studies gradually unveil overall themes in their chronological ordering. The connection between interwar French critics of African American music hall shows and post-WWII jazz criticism reveals not only the existence, but endurance of, racialist and primitivist tropes among critics (conservative and progressive). Of course not all of these critics were laudatory, and the reception of African American music also reflects "an ambivalent coexistence of liberal and reactionary tendencies, on music, race, and culture."

Even more significantly, Fry inventively reads through and around these critical reviews to arrive at the ways in which African American music and

Gone Primitive: Savage Intellects, Modern Lives (Chicago: University of Chicago Press, 1990); and Ludovic Tournès, New Orleans sur Seine: Histoire du Jazz en France (Paris: Fayard, 1999).

${ }^{3}$ Namely, early works such as Chris Goddard, Jazz Away from Home (New York: Paddington Press, 1979) and Bill Moody, The Jazz Exiles: American Musicians Abroad (Reno, Nev.: University of Nevada Press, 1993) and the memoirs of musicians, most famously Sidney Bechet, Treat it Gentle (London: Cassell, 1960) and even that of singer and nightclub owner, Ada "Bricktop" Smith; Bricktop with James Haskins, Bricktop (New York: Atheneum, 1983). Of more recent histories he finds fault with the generally positive portrayal of the French racial climate in Tyler Stovall, Paris Noir: African Americans in the City of Light (Boston: Houghton Mifflin, 1996) and William Shack, Harlem in Montmartre: A Paris Jazz Story Between the Great Wars (Berkeley: University of California Press, 2001).

${ }^{4}$ Fry, 78. 
performance could be used to serve ideological ends. French critical resentment against the enormously popular Jack Hylton and his "American"-style band (Hylton was in fact British) quite easily turned into the attempt by some armchair musicologists to "naturalize" jazz and locate its supposed French expression and origins in the homegrown talent of Django Reinhardt or in the Creole culture of the American south.

From there it becomes quite natural for a jazz writer and impresario like Charles Delaunay to "invent" a history of jazz that couched it within, as he claimed, the French musical tradition in order to hide it under the nose of Vichy officials. Fry convincingly demonstrates how the myth of jazz as the music of the resistance is largely a postwar construction, as is the notion that Occupation-era jazz was preeminent among the rebellious counterculture of zazou youth.

He uses compelling examples, revealing the gap between, for instance, Delaunay's myth-making in his memoir, De la vie et du jazz (1945), as opposed to the reality revealed in his wartime correspondence. ${ }^{5}$ Fry also reflects on the extensive popularity of Django Reinhardt during these years and Reinhardt's at times worryingly close interactions with the Nazi regime. This is best captured in an incredible photograph, which unfortunately is not given Fry's otherwise rigorous treatment of sources. The photo is included, with only a brief description informing us that it depicts Luftwaffe officer Dietrich SchulzKöhn with Reinhardt and five other jazz musicians, four of whom are colonial black musicians and one of whom is Jewish.

The case of Schulz-Köhn is a missed opportunity that would have added to Fry's appeal for more complex histories of jazz during the Second World War. A passionate jazz fan, Köhn was a budding jazz critic and had corresponded with Delaunay and Hugues Panassié as a young graduate student before the outbreak of the war. Once Köhn was assigned to France, he often used his position to shield jazz clubs and musicians, at great personal risk. ${ }^{6}$ The assistance was mutual: on the date of Germany's surrender Köhn was taken

\footnotetext{
${ }^{5}$ Bruce Epperson agrees, and he writes that the involvement of the Hot Club with the Resistance was not the result of planned collaboration: "After a while the French underground started using it [the Hot Club] as a message center, certainly with Delaunay's tacit acquiescence, and possibly by explicit arrangement." Epperson, More Important Than the Music: A History of Jazz Discography (Chicago: The University of Chicago Press, 2013), 44.

${ }^{6}$ One of those who were fortunate enough to encounter Köhn's assistance was Henri Battut, a French Jew, who is pictured in the aforementioned photograph. He was in hiding at the time of the photo and Köhn helped provide for him with food stamps. Michael H. Kater. Different Drummers; Jazz in the Culture of Nazi Germany (New York: Oxford University Press, 1992), 199.
} 
prisoner by the Americans, and it was Panassié and Delaunay who sent him letters and care packages. ${ }^{7}$ Although Michael Kater and to a lesser extent, Bruce Epperson, have written about Schulz-Köhn, he seems to illustrate perfectly Fry's central point, that “celebrating jazz's resistance or denouncing its collaboration is not only simplistic but anachronistic in the context of a period when politics were not so much polarized as they were all multicolored hues." ${ }^{8}$

Perhaps such a discussion would have been more relevant if this were a book about the musicians themselves, which Fry clearly states it is not. ${ }^{9}$ However, it might have contributed to his argument that France was not an Edenic refuge for African Americans abroad. To that end neither does Fry expand (it gets only a brief mention) upon the legislation limiting the number of foreign musicians in French bands. The timeline of these laws in France are reflective of Fry's discerning of an early nationalist and xenophobic sentiment far before the postwar years. Beginning in 1922 French musicians were clamoring for the government to legislate against (as they called it) le péril noir, and finally that legislation came first in 1936, when the number of foreign musicians permitted in a French band was limited to thirty percent, and then again in 1939, when it was cut down even further to ten percent. ${ }^{10}$ Jeffrey $\mathrm{H}$. Jackson has already contributed to an understanding of the labor tensions between French and foreign musicians that led to the passage of the law, but this does not preclude Fry from an attempt of his own. ${ }^{11}$

\footnotetext{
${ }^{7}$ Ibid., 199.

${ }^{8}$ Fry, 209.

${ }^{9}$ The memoirs and interviews of expatriate jazz musicians have been widely analyzed and in the case of Paris, Fry rightly points out that these sources can sometimes perpetuate the mythology of a city free of racial prejudice. On occasion, however, they can also do the reverse. In an interview Donald Byrd matter-of-factly responded to the question of whether Europeans respected African American jazz musicians. "If you look at it from an economical standpoint, hell no, because as soon as you would come over there, the first time they would pay you like hell. The next time was half the money and the third time around it would be down to whatever the local musicians made. A classical musician in Europe is treated like a classical musician over here. His price does not go down. If they really respected the black musician like a classical musician then his price would not have gone down." Ursula Broschke Davis. Paris Without Regret: James Baldwin, Kenny Clarke, Chester Himes, and Donald Byrd (Iowa City: University of Iowa Press, 1986), 108.

${ }^{10}$ Michael Dregni. Django: The Life and Music of a Gypsy Legend. (Oxford: Oxford University Press, 2006), 98.

${ }^{11}$ Particularly since Fry disputes Jackson's interpretation of the "naturalization" of French jazz, and the legislation would have presented further proof that "Jackson's premise - that 'making jazz French' signals an openness to outside influences rather than, say, a desire to absorb and hence defuse them - does not always seem sound" (17). Jeffrey H. Jackson. Making Jazz French: Music and Modern Life in Interwar Paris. (London: Duke University Press, 2003).
} 
One of the more provocative sections of the book deals with the legacy of Ernest Alexandre Ansermet. The Swiss conductor's glowing review of Sidney Bechet and Will Marion Cook's Southern Syncopated Orchestra in 1919 has been touted by writers from Gunther Schuller to Gary Giddins as the leading example of the intellectually perceptive reception jazz received in Europe. Fry finds it justifiably disconcerting that few scholars have reckoned with the actual language used to describe Bechet, "this very black, fat boy, with white teeth and a low brow, who is very glad one likes what he does, but who can say nothing of his art, save that he follows in his 'own way." 12 For Laurent Cugny the accusation of paternalism is "an anachronism," but Fry's reading of Ansermet's criticism is ultimately an essential and important contribution to the history of so ambivalent a figure as Ansermet. ${ }^{13}$

Monographs about discourse and audience reception always run the risk of shunting the imaginative work of musicians and performers from one solemn analytical category to the next. Fry manages to tell this history without minimizing the careers of the performers in question, especially in the chapters on Josephine Baker and Sidney Bechet. He demonstrates that African Americans were not passive and helpless observers, but active agents in the modulation of their effect upon French audiences. Of Baker, for example, Fry writes, "And if there never was a 'savage' Baker to be 'civilized,' the colonial discourse that sought to view her transformations in such terms collapses. In its place I locate an intelligent actor who pandered to her audience's imaginations at one moment but challenged them the next." ${ }^{14}$

The discussion of Bechet's attempt to shape the public memory of himself and of jazz are noteworthy, and Fry proves that Bechet's memoir Treat it Gentle is always fighting against a romanticization of his past. The analysis of jazz and public memory induce Fry into one of the more poetic and delicate passages of the book, in which he traces Bechet's musical progression in France. Gradually moving from a riff with the simplest of counterpoints such as "Les Oignons" to the complex "Petite Fleur," "a tune that has no deep roots but somehow sounds as if it must," Bechet plays with "such rhetorical force

\footnotetext{
${ }^{12}$ Ernest Ansermet. "Sur un orchestre nègre," Écrits sur la musique (Paris: La Baconniere, 1983) in Fry, 226.

${ }^{13}$ Cugny elaborates, "As far as the global vision of African Americans is concerned, the collective acuity of these numerous subtle observations largely balances some representations that appear problematic to our twenty-first century understanding, but which were not so at the time.” Laurent Cugny, “Did Europe 'Discover' Jazz?” in Luca Cerchiari, Laurent Cugny, Franz Kershbaumer, editors. Eurojazzland: Jazz and European Sources, Dynamics and Contexts (Boston, MA: Northeastern University Press, 2012), 310.

${ }^{14}$ Fry, 168.
} 
that it is tempting to hear this revelatory moment itself as an act of remembering." 15

In a way, Bechet's memoir arrived at a point when concern about locating the origins of jazz had become a pressing issue as its founding generation passed away. In fact, Fry suggests one of the more enduring contributions to the popular understanding of jazz might be traced to Charles Delaunay in De la vie et du jazz, where Delaunay claims that he "invented" the view that jazz was a universal folk tradition. The appeal of a universal jazz culture is obvious, as is its offense. On the one hand it seems to recognize the worldwide flowering of jazz and on the other, negate or rob the music of its African American origin and context. Yet the idea persisted: only two years after the 1960 termination date of Fry's study, the Kenny Clarke and Francy Boland Big Band would title their album, "Jazz is Universal" and even today scholars are apt to take up the challenge of the possibility of a universal jazz idiom. ${ }^{16}$

To return to James Baldwin's anecdote, his frustration stemmed from the fact that French appreciation for jazz was undercut by the assumption that music was the only art that an African American could practice, let alone excel in. A great deal of Paris Blues shows how "debates ostensibly about art often disguised ones about race, and virulent nationalism hid its head as mere patriotism," but Fry rightly adds that race was not the only issue at stake. "Jazz engages too many touchstone issues of the twentieth century for any simple explanation to do justice to its very complex reception, which embraces modernity, technology, and global reconfigurations of power, cultural as well as political." 17

In Fry's thoroughly researched and elegantly written book, these issues and their stakes are clear. French and European jazz appreciation fell within problematic rubrics, and Fry helps us move towards an understanding of the continued importance and relevance of these debates. His nuanced account of this complexity gives us a far better historical picture of African Americans in Paris, one that moves away from the simple tropes of the Martin Ritt film that gives the book its title and features in its introductory and closing remarks. In response to Eddie Cook's (the role played by Sidney Poitier) exasperated question in the film, "Look, are we gonna stand here all day discussing this

\footnotetext{
${ }^{15}$ Fry, 261.

16 See Eurojazzland for an example of scholars doing just this. The orthodox view of individuals such as Wynton Marsalis, Stanley Crouch, and Albert Murray would define jazz as that music which strictly contains elements of the blues and swing, as opposed to the freer forms that have evolved in Europe and owe little to either of those two traditions.

17 Fry, 268.
} 
jazz?" a reader might be inclined to respond: only until we have more such studies as this.

\section{About the Contributor}

Merve Fejzula is an MPhil student in Historical Studies at the University of Cambridge, whose current project is about the history of black intellectuals in post-World War II Paris. She graduated from Rutgers University-Newark in 2011 with a double major in English and history and a minor in philosophy. Before embarking upon graduate study at Cambridge, she served as program coordinator of the Diversity Research Center, which also included collaboration on special projects with Rutgers' Institute of Jazz Studies.

The Journal of Jazz Studies (JJS) is published by the Institute of Jazz Studies at the Newark campus of Rutgers, The State University of New Jersey. JJS is hosted online by the Rutgers University Libraries at http://jjs.libraries.rutgers.edu. 